\title{
PERBEDAAN RATA-RATA LINGKAR PERUT, KONSUMSI KARBOHIDRAT, DAN NATRIUM LANSIA HIPERTENSI PRIMER STAGE 1 DENGAN STAGE 2 PUSKESMAS ARJUNO KOTA MALANG
}

\author{
Agatha Derta Donira, Diah Mulyawati Utari \\ (Pascasarjana Peminatan Gizi Fakultas Kesehatan Masyarakat Universitas Indonesia)
}

\begin{abstract}
The risk factors for hypertension are abdominal obesity, carbohydrate and sodium intake. The purpose of this study to determine the average difference in abdominal circumference, carbohydrate, and sodium consumption in elderly patients with stage 1 primary hypertension and stage 2 in the Arjuno Public Health, Malang City. The research method used a cross sectional design, during November 2016. The sampling technique used purposive sampling, the inclusion criteria were aged $\geq 55$ years and suffering from primary hypertension. Abdominal circumference was measured using metlin, carbohydrate and sodium consumption obtained from a 1x24 hour recall interview. Data analysis used independent $t$ test and Mann Whitney. The results showed that there was a difference in the average sodium consumption of the elderly with stage 1 primary hypertension and stage 2 from a significant $p$-value $(p=0,032)$. Meanwhile, abdominal circumference and carbohydrate intake did not show an average difference between the elderly with primary hypertension stage 1 and stage 2 ( $p=0,580 ; p=0,332)$. The results showed that there was no difference in the average abdominal circumference and carbohydrate consumption with the hypertension stage, but there was an average difference between sodium consumption in the elderly with primary hypertension stage 1 and stage 2 . It is recommended to provide education to the elderly in the work area of the Arjuno Health Center Malang City about a balanced nutritional diet, low in carbohydrates, and low in sodium to keep his blood pressure more stable. Further research to widen the age range towards a younger and increase the number of samples.
\end{abstract}

Keywords: Abdominal Circumference; Carbohydrates; Sodium; Hypertension

\begin{abstract}
Abstrak
Faktor risiko penyakit hipertensi adalah obesitas abdominal, asupan karbohidrat, dan natrium. Tujuan penelitian ini untuk mengetahui perbedaan rata-rata lingkar perut, konsumsi karbohidrat, dan konsumsi natrium lansia penderita hipertensi primer stage 1 dengan hipertensi primer stage 2 di lingkungan kerja Puskesmas Arjuno Kota Malang. Metode penelitian ini menggunakan desain penelitian cross sectional, selama bulan November 2016. Teknik sampling menggunakan purposive sampling, kriteria inklusi usia $\geq 55$ tahun dan menderita hipertensi primer. Lingkar perut diukur menggunakan metlin, konsumsi karbohidrat dan natrium didapat dari wawancara recall $1 \times 24$ jam. Analisis data menggunakan uji statistik $t$ tak berpasangan dan Mann Whitney. Hasil penelitian menunjukkan terdapat perbedaan rata-rata konsumsi natrium lansia hipertensi primer stage 1 dengan stage 2 dari nilai signifikan $p$-value $(p=0,032)$. Sedangkan lingkar perut dan asupan karbohidrat tidak menunjukkan perbedaan rata-rata antara lansia hipertensi primer stage 1 dengan stage $2(p=0,580 ; p=0,332)$. Hasil penelitian menunjukkan tidak terdapat perbedaan rata-rata lingkar perut dan konsumsi karbohidrat dengan stage hipertensi, namun terdapat perbedaan rata-rata antara konsumsi natrium pada lansia penderita hipertensi primer stage 1 dengan stage 2. Disarankan adanya pemberian edukasi kepada lansia di wilayah kerja Puskesmas Arjuno Kota Malang tentang pola makan gizi seimbang, rendah karbohidrat, dan rendah natrium untuk menjaga tekanan darahnya lebih stabil. Penelitian lebih lanjut untuk memperlebar rentang umur ke arah lebih muda dan memperbanyak jumlah sampel.
\end{abstract}

Keywords: Lingkar Perut; Karbohidrat; Natrium; Hipertensi 


\section{PENDAHULUAN}

Hipertensi dikenal sebagai salah satu penyakit tidak menular yang menyebabkan kematian prematur di dunia. Sebutan "silent killer"atau "pembunuh senyap" identik dengan penyakit hipertensi. ${ }^{1}$ Tinjauan tren saat ini secara global menunjukkan hipertensi pada orang dewasa meningkat dari 594 juta tahun 1975 menjadi 1,13 miliar pada tahun 2015, sebagian besar pada beberapa negara berpenghasilan menengah ke bawah. ${ }^{2}$ Berdasarkan Riskesdas tahun 2018, prevalensi hipertensi di Indonesia meningkat dari tahun 2013 sebesar $25,8 \%$ menjadi $34,1 \%$ pada tahun 2018. Berdasarkan hasil pengukuran tekanan darah pada penduduk $\geq 18$ tahun Provinsi Jawa Timur menempati urutan ke-6 dari seluruh Provinsi di Indonesia. Proporsi penduduk wilayah perkotaan $(34,4 \%)$ lebih besar dibandingkan wilayah perdesaan $(33,7 \%)$, tren prevalensi hipertensi berdasarkan diagnosis dokter cenderung meningkat seiring bertambahnya usia. ${ }^{3}$ Berdasarkan data Dinas Kesehatan Kota Malang prevalensi penderita hipertensi di Kota Malang meningkat dari tahun 2014 sebesar 23,9\% menjadi 40,1\% tahun $2015 .{ }^{4}$

Obesitas utamanya obesitas abdominal menjadi faktor risiko peningkatan tekanan darah dan kadar trigliserida, yang kemudian menyebabkan faktor risiko kardiovaskular. ${ }^{5}$ Kategori obesitas menurut Kementerian Kesehatan RI adalah apabila ukuran lingkar pinggang >90 cm (pria) serta $>80 \mathrm{~cm}$ (wanita) didasarkan pada grup etnis Asia Selatan, populasi China, Melayu dan Asia-India. ${ }^{6}$ Salah satu faktor penyebab obesitas yaitu konsumsi tinggi karbohidrat. Konsumsi karbohidrat berlebih mungkin menjadi salah satu penyebab obesitas, sehingga meningkatkan kejadian penyakit kardiovaskular salah satunya hipertensi .

Natrium ( $\mathrm{Na}$ ) dengan klorida $(\mathrm{Cl})$ yang terkandung dalam garam dapur berfungsi mempertahankan keseimbangan cairan tubuh juga mengatur tekanan darah. Namun, apabila natrium berlebihan di dalam darah justru menahan air menyebabkan volume darah meningkat, memicu tekanan pembuluh darah, sehingga beban kerja jantung meningkat. Perubahan struktur dan fungsi pembuluh darah kemungkinan menyebabkan hipertensi, semakin bertambah usia, fungsi pembuluh darah berkurang, pengerasan pada pembuluh darah, dan mempengaruhi tekanan darah. ${ }^{8}$

Komite Nasional Bersama dengan sebutan Joint National Committe on Prevention Detection, Evaluation, and Treatment or High Pressure (JNC) VII mendefinisikan hipertensi sebagai keadaan tekanan darah sistolik seseorang $\geq 140 \mathrm{mmHg}$ atau tekanan darah diastoliknya $\geq 90 \mathrm{mmHg}$. Klasifikasi tekanan darah untuk pasien dewasa (umur $\geq 18$ tahun) dibagi menjadi 4 yaitu normal, prahipertensi, hipertensi stage 1 , dan hipertensi stage $2 .^{9}$ Berdasarkan Pusdatin Kemenkes RI (2019) menyatakan peningkatan tekanan darah yang terjadi dan berlangsung cukup lama pada pasien hipertensi stage 1 maupun stage 2 mampu menimbulkan kerusakan pada ginjal (gagal ginjal), jantung (penyakit jantung koroner), dan otak (stroke) apabila tidak dideteksi secara dini dan mendapat pengobatan yang memadai. ${ }^{10}$ 
Penelitian Anggraini (2016) menyatakan sebagian besar penderita hipertensi primer terjadi di atas usia 50 tahun karena saat usia produktif jarang memperhatikan kesehatannya. ${ }^{11}$ Berdasarkan penelitian Yulanda dan Lisiswanti (2017) menyatakan didasarkan penyebab hipertensi, maka dibagi menjadi hipertensi primer (esensial) yang etiologi patofisiologinya tidak diketahui dan hipertensi sekunder. ${ }^{12}$ JNC VII menyatakan hipertensi sekunder sudah diketahui penyebabnya seperti kelainan pembuluh darah ginjal, penyakit tiroid dan paratiroid, hiperaldosteronisme serta masih banyak lagi. ${ }^{9}$

Berdasarkan studi pendahuluan peneliti di Puskesmas Arjuno Kota Malang, prevalensi penderita hipertensi tahun 2015 sebesar 21,1\%, dan meningkat pada tahun 2016 dari bulan Januari sampai dengan bulan Juni sebesar $31 \%$. Berdasarkan hal-hal di atas, peneliti ingin menganalisis perbedaan rata-rata lingkar perut, konsumsi karbohidrat, dan konsumsi natrium lansia penderita hipertensi primer stage 1 dengan hipertensi primer stage 2 di lingkungan kerja Puskesmas Arjuno Kota Malang.

\section{METODE PENELITIAN}

Jenis penelitian ini adalah analitik dengan desain penelitian cross sectional. Penelitian ini dilakukan selama bulan November 2016. Populasi penelitian ini adalah semua lansia hipertensi primer di wilayah kerja Puskesmas Arjuno Kota Malang. Sampel penelitian ini adalah lansia dengan hipertensi primer di wilayah Kerja Puskesmas Arjuno Kota Malang sejumlah 37 responden yang menggunakan teknik purposive sampling. Kriteria inklusi adalah lansia usia $\geq 55$ tahun, tempat tinggal di wilayah Puskesmas Arjuno Kota Malang, telah diukur tekanan darahnya minimal tiga kali dan dinyatakan menderita hipertensi primer. Cut off hipertensi primer stage I yaitu tekanan darah sistolik antara $140 \mathrm{mmHg}-159 \mathrm{mmHg}$, sedangkan hipertensi primer stage 2 adalah $\geq 160 \mathrm{mmHg} .{ }^{9}$ Kriteria eksklusi yaitu menderita penyakit lain seperti Diabetes Mellitus, Stroke, Gagal Ginjal Kronik, dan Penyakit Jantung Koroner.

Variabel bebas penelitian ini yaitu rata-rata lingkar perut, konsumsi karbohidrat, dan natrium, sedangkan variabel terikatnya adalah lansia penderita hipertensi primer stage 1 dan stage 2. Pengukuran lingkar perut menggunakan Metlin merk Elber HL0101 dengan ketelitian $0,1 \mathrm{~cm}$. Cara pengukuran lingkar perut responden berdiri tegak dan tidak diperkenankan menahan perut saat diukur lingkar perutnya, sedangkan instrument untuk pengumpulan data konsumsi karbohidrat dan natrium menggunakan food recall 1x24 jam selanjutnya dianalisis dengan program Nutrisurvey 2007. Data yang sudah diolah dan dientry kemudian dianalisis menggunakan program analisis statistik. Data diuji kenormalannya menggunakan Shapiro-Wilk dan untuk analisis perbedaan rata-rata pada dua kelompok populasi yang berdistribusi normal menggunakan uji $\mathrm{t}$ tak berpasangan, sedangkan uji Mann Whitney digunakan untuk variabel data berdistribusi tidak normal. ${ }^{13}$ 


\section{HASIL PENELITIAN}

Penelitian ini dilaksanakan selama bulan November 2016, didapatkan jumlah sampel 37 responden didasarkan pada kriteria inklusi. Karakteristik responden dapat dilihat pada Tabel 1.

Tabel 1. Distribusi Frekuensi berdasarkan Karakteristik Jenis Kelamin, Umur, Riwayat Keturunan Hipertensi, dan Tekanan darah Sistolik Lansia di Lingkungan Puskesmas Arjuno Kota Malang

\begin{tabular}{|c|c|c|}
\hline Karakteristik & f & $\%$ \\
\hline \multicolumn{3}{|l|}{ Jenis kelamin } \\
\hline Laki & 7 & 18,92 \\
\hline Perempuan & 30 & 81,08 \\
\hline Total & 37 & 100 \\
\hline \multicolumn{3}{|l|}{ Umur } \\
\hline 55-64 tahun & 14 & 37,84 \\
\hline $65-74$ tahun & 17 & 45,95 \\
\hline 75 tahun ke atas & 6 & 16,21 \\
\hline Total & 37 & 100 \\
\hline \multicolumn{3}{|l|}{ Riwayat keturunan hipertensi } \\
\hline Ada & 12 & 32,43 \\
\hline Tidak ada & 25 & 67,57 \\
\hline $\begin{array}{c}\text { Total } \\
\end{array}$ & 37 & 100 \\
\hline \multicolumn{3}{|l|}{ Tekanan darah sistolik (mmHg) } \\
\hline $140-159$ (hipertensi stage 1) & 16 & 43,24 \\
\hline$\geq 160$ (hipertensi stage 2) & 21 & 56,76 \\
\hline Total & 37 & 100 \\
\hline
\end{tabular}

Distribusi karakteristik lansia yang disajikan pada Tabel 1. menunjukkan bahwa sebagian besar sampel merupakan lansia berjenis kelamin perempuan 30 responden $(81,08 \%)$, berusia 65 sampai dengan 74 tahun sejumlah 17 responden $(45,95 \%)$, tidak memiliki riwayat keturunan hipertensi dari orang tuanya 25 responden (67,57\%), dan memiliki tekanan darah $\geq 160 \mathrm{mmHg}$ dikategorikan sebagai hipertensi primer stage 2 sejumlah 21 responden (56,76\%). Hasil uji statistik Nilai mean, standar deviasi, minimum dan maksimum konsumsi lingkar perut, konsumsi karbohidrat, dan natrium disajikan pada Tabel 2.

Tabel 2. Hasil Statistik Deskriptif dan Uji Beda Rata-rata Lansia Hipertensi Primer Stage I dengan Stage 2 di Puskesmas Arjuno Kota Malang

\begin{tabular}{|c|c|c|c|c|c|c|c|}
\hline \multirow[t]{2}{*}{ Variabel } & \multicolumn{3}{|c|}{ HT Stage 1} & \multicolumn{3}{|c|}{ HT Stage 2} & \multirow{2}{*}{$\begin{array}{c}p- \\
\text { value }\end{array}$} \\
\hline & Mean \pm SD & Min & Max & Mean \pm SD & Min & Max & \\
\hline LP (cm) & $90,9 \pm 10,9$ & 66,5 & 110,0 & $93,1 \pm 12,8$ & 70,0 & 115,0 & 0,580 \\
\hline Karbohidrat (g) & $142,7 \pm 57,8$ & 59,6 & 225,1 & $157,7 \pm 39,4$ & 79,6 & 265,4 & 0,332 \\
\hline Natrium (mg) & $\begin{array}{c}706,7 \pm \\
600,6\end{array}$ & 232,7 & 2376,2 & $1071,9 \pm 635,9$ & 216,9 & 2423,7 & 0,032 \\
\hline
\end{tabular}

Hasil uji statistik dapat dilihat pada Tabel 2 menunjukkan tidak terdapat perbedaan ratarata secara bermakna antara lingkar perut dengan stage hipertensi $(p=0,580)$, namun terdapat kecenderungan bahwa rata-rata lingkar perut pada hipertensi stage $2(93,1 \mathrm{~cm})$ 
dengan varian 12,8 $\mathrm{cm}$ lebih besar dibanding lingkar perut pada hipertensi stage $1(90,9 \mathrm{~cm})$ dengan varian 10,9 cm. Demikian juga nilai minimal $(66,5 \mathrm{~cm})$ dan maksimal $(110 \mathrm{~cm})$ lingkar perut yang lebih besar pada kelompok hipertensi stage 2. Sejalan dengan lingkar perut, tidak terdapat hubungan antara konsumsi karbohidrat dengan stage hipertensi $(p=0,332)$, namun terdapat kecenderungan bahwa rata-rata konsumsi karbohidrat pada kelompok hipertensi stage $2(157,7 \mathrm{~g})$ dengan varian $39,4 \mathrm{~g}$ lebih besar dibanding pada kelompok hipertensi stage $1(142,7 \mathrm{~g})$ dengan varian 57,8 g. Demikian juga dengan nilai minimal $(59,6 \mathrm{~g})$ dan maksimalnya $(225,1 \mathrm{~g})$. Dari ketiga variabel independen, hanya konsumsi Natrium yang memiliki perbedaan rata-rata secara bermakna dengan stage hipertensi $(p=0,032)$, terlihat bahwa rata-rata konsumsi natrium lebih banyak pada kelompok hipertensi stage 2 (1071,9 mg) dengan varian 635,9 mg dibanding pada kelompok hipertensi stage 1 (706,7 mg) dengan varian 600,6 mg.

Lebih lanjut pola hubungan antar variabel ditunjukkan dengan Scatter diagram pada gambar 1, gambar 2, dan gambar 3 .

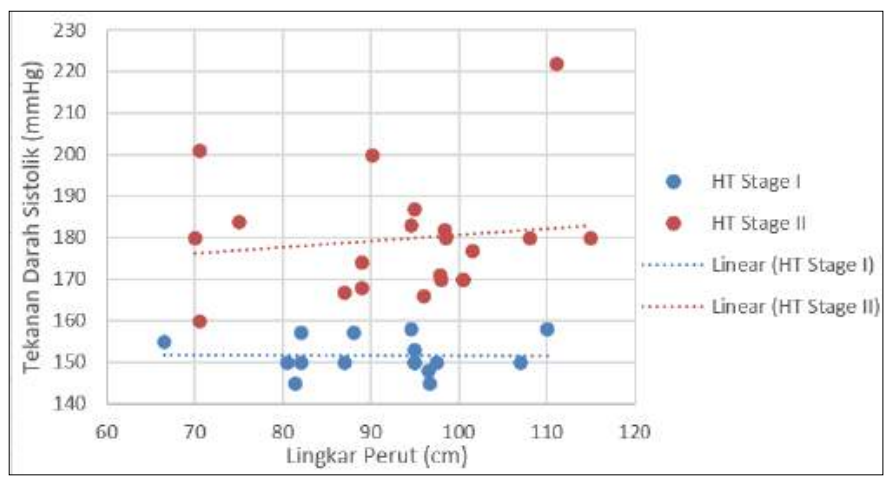

Gambar 1. Lingkar Perut berdasarkan Stage Hipertensi

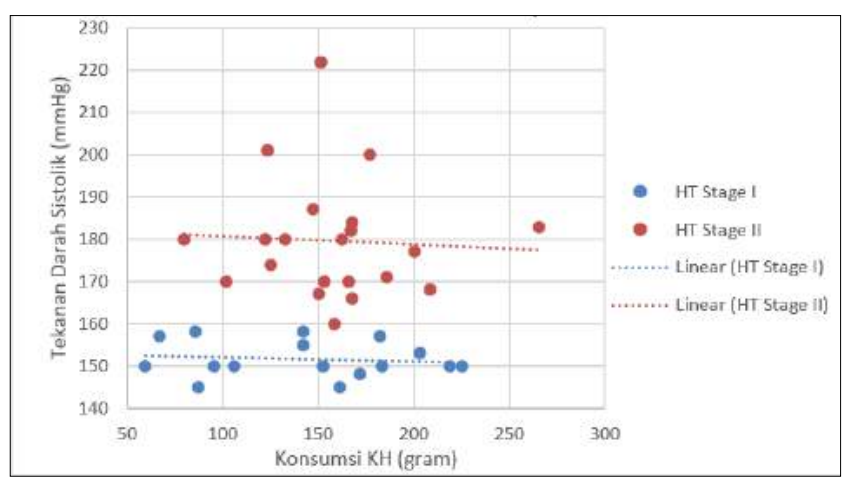

Gambar 2. Konsumsi Karbohidrat berdasarkan Stage Hipertensi

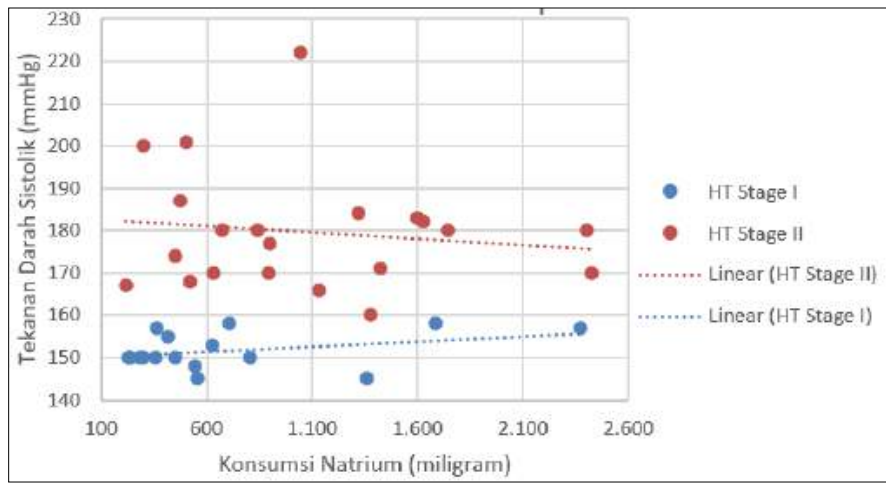

Gambar 3. Konsumsi Natrium berdasarkan Stage Hipertensi

Pada gambar 1, gambar 2, dan gambar 3 terlihat adanya kedekatan dari dua data dengan menggambarkan suatu penyebab masing-masing variabel independen (lingkar perut, asupan karbohidrat, dan natirum) terhadap variabel dependen (tekanan darah sistolik lansia). Pada masing-masing diagram tersebut digambarkan dua kelompok tekanan darah 
lansia ditunjukkan dengan warna plot biru untuk kelompok lansia dengan hipertensi primer stage I, sedangkan warna plot merah untuk kelompok lansia hipertensi primer stage II. Adanya garis linear sesuai warna plot kelompok membantu melihat kecenderungan perbedaan rata-rata tekanan darah antara dua kelompok stage hipertensi. Signifikansi perbedaan rata-rata dapat dilihat analisis uji statistiknya pada tabel 3. Pada gambar 1 tampak jumlah responden yang ukuran lingkar perutnya semakin besar cenderung semakin tinggi tekanan darah sistoliknya. Pada gambar 2 tidak ada kecenderungan konsumsi karbohidrat berkaitan dengan tekanan darah lansia. Pada gambar 3 tampak bahwa semakin rendah konsumsi natriumnya cenderung semakin rendah tekanan darah sistoliknya.

\section{PEMBAHASAN}

Hasil analisis statistik terhadap lingkar perut dan konsumsi karbohidrat kedua kelompok penelitian menggunakan uji t tak berpasangan. Tidak terdapat perbedaan rata-rata yang bermakna pada lingkar perut lansia penderita hipertensi primer stage 1 dengan hipertensi primer stage $2(p=0,580)$. Hasil penelitian ini sejalan dengan hasil penelitian Fauza dan Rosidi (2017) bahwa LP (Lingkar Perut) sebagai indikator pengklasifikasian risiko hipertensi masih dianggap belum cukup baik, dengan ditunjukkan sensitivitas LP 0,87 (87\%) dan spesifisitasnya yaitu $0,71(71 \%){ }^{14}$

Dalam penelitian Rumahorbo et al. (2020) menyatakan bahwa pada hipertensi primer (esensial), faktor genetik mempengaruhi tingginya risiko terjadinya hipertensi. Faktor genetik atau riwayat keluarga merupakan anggota keluarga yang memiliki riwayat hipertensi. Faktor genetik ini juga dipengaruhi oleh faktor-faktor lain. Penuaan atau aging di berbagai negara dan wilayah menjadi faktor penyebab peningkatan tekanan darah. Usia yang lebih tua dianggap konsisten terhadap hipertensi berdasarkan dari signifikan kejadian hipertensi. Signifikan hipertensi lebih tinggi terjadi pada orang dewasa yang lebih tua dibanding dengan yang lebih muda. Faktor ras campuran pada lansia lebih tinggi kejadian hipertensi primernya dibandingkan ras kulit hitam, putih, ras Asia dan ras Indian, hal tersebut berkaitan dengan perbedaan sosial, budaya, diet serta pola hidup. ${ }^{15}$ Untuk itu faktor risiko terjadinya hipertensi yang sering dihubungkan dengan lingkar perut ataupun obesitas sentral bukan menjadi satusatunya faktor penyebab hipertensi. Ada faktor lain dari penelitian ini yang tidak bisa diperkirakan dan faktor yang tidak bisa dimodifikasi seperti jenis kelamin, usia, riwayat keluarga, dan juga ras.

Rata-rata konsumsi karbohidrat pada penelitian ini menunjukkan tidak ada perbedaan rata-rata secara statistik antara konsumsi karbohidrat lansia penderita hipertensi primer stage 1 dengan stage 2 ( $p=0,332$ ). Hal ini sejalan dengan penelitian Mulyasari dan Srimiati (2020) menyatakan bahwa dalam penelitiannya tidak terdapat hubungan antara konsumsi karbohidrat dengan kejadian hipertensi. ${ }^{16}$ Listiana (2017) dalam penelitiannya juga 
mengatakan bahwa tidak terdapat hubungan antara asupan karbohidrat dengan tekanan darah pada penderita hipertensi. ${ }^{17}$

Dalam penelitian Fadillah et al. (2019) menyatakan bahwa faktor yang memengaruhi kejadian hipertensi disebabkan pada umur lansia yang lebih tua dan penurunan frekuensi kebiasaan sarapan dibandingkan lansia yang lebih muda. Hal tersebut terjadi karena proses penuaan terus berlangsung seiring bertambahnya usia lansia, menyebabkan timbulnya beberapa gangguan kesehatan, salah satunya yaitu gangguan pencernaan. ${ }^{18} \mathrm{Hal}$ ini sejalan dengan penelitian Kurnianingtyas et al. (2017) bahwa responden lansia banyak mengonsumsi nasi, soto, kentang goreng, pati, cilok, cireng, oats, jagung serut dan tepung tapioka yang merupakan sumber karbohidrat kompleks. Beberapa makanan tersebut termasuk dalam karbohidrat kompleks yang bukan menjadi faktor risiko terjadinya hipertensi. Minuman bergula, jelly atau puding, susu sapi yang merupakan jenis karbohidrat sederhana hanya dikonsumsi oleh beberapa responden. ${ }^{19}$ Maka dari itu penyebab tidak adanya perbedaan rata-rata konsumsi karbohidrat lansia antar stage hipertensi dalam penelitian ini diperkirakan karena jenis karbohidrat yang dikonsumsi oleh responden lebih mengarah pada jenis karbohidrat kompleks dibandingkan karbohidrat sederhana, dan frekuensi makan lansia yang semakin menurun akibat perubahan fisiologis pada organ pencernaan seperti gigi serta proses kimiawi seperti pengeluaran enzim saat proses pencernaan.

Hasil analisis statistik terhadap konsumsi natrium kedua kelompok menggunakan uji Mann Whitney dikarenakan data konsumsi natrium lansia penderita hipertensi primer stage 1 tidak memenuhi normalitas data. Hasil statistik menunjukkan bahwa terdapat perbedaan rata-rata yang bermakna pada variabel konsumsi natrium lansia penderita hipertensi primer stage 1 dengan stage $2(p=0,032)$. Hal tersebut sejalan dengan penelitian Yulistina et al. (2017) bahwa pada usia menopause faktor yang paling dominan mempengaruhi hipertensi adalah asupan natrium. ${ }^{20}$ Fayasari dan Salindri (2016) dalam penelitiannya menyatakan bahwa terdapat perbedaan rata-rata signifikan pada asupan natrium dan rasio $\mathrm{Na}-\mathrm{K}$ dari hasil analisis uji ANOVA. Ada kecenderungan peningkatan rata-rata asupan seiring meningkatnya stage hipertensi. ${ }^{21}$

Retensi air dapat dipicu konsumsi garam yang meningkat, sehingga mengakibatkan kondisi aliran tinggi di pembuluh arteri. Asupan natrium diatur oleh mekanisme saraf yang mengatur asupan natrium dan sistem homoeostasis terkait. Restriksi natrium menghasilkan peningkatan aterosklerosis. Hasil tekanan darah yang tinggi dalam interval waktu yang lama menyebabkan perubahan struktural progresif di dinding arteri dari berkaitan dengan elastisitas pada arteri besar, dengan konsekuensi peningkatan kekakuan arteri. Peningkatan ekspresi serat kolagen, dan akibat penurunan rasio antara serat elastin dan kolagen, yang dapat menyebabkan peningkatan pengerasan dinding arteri secara progresif. Asupan natrium yang berlebihan dalam diet menginduksi perubahan pada matriks ekstraseluler 
dinding arteri, yang mendukung proses pengerasan arteri. Disfungsi endotel dan stres oksidatif yang berkaitan dengan asupan natrium yang tinggi dapat menyebabkan kerusakan pembuluh darah melalui mekanisme yang tidak bergantung pada tekanan. Asupan natrium yang tinggi menyebabkan aktivasi matriks ekstraseluler metaloproteinase MMP2 dan MMP9, menyebabkan stimulasi TGFß-1, mengakibatkan penipisan dan kerusakan serat elastin serta penurunan rasio elastin juga kolagen. Fibrosis arteri yang dipercepat mungkin berperan penting atas peningkatan kekakuan arteri dan amplifikasi kerusakan vaskular terkait penuaan. Asupan natrium yang tinggi dengan diet juga tampaknya dapat merangsang reseptor aorta Angiotensin II tipe 1 (reseptor AT1), dan kerusakan vaskular yang disebabkan oleh asupan natrium yang berlebihan dapat dimodulasi oleh faktor genetik, khususnya oleh polimorfisme AT1 gen reseptor dan gen sintase aldosteron. Polimorfisme genetik ini tampaknya memiliki relevansi khusus pada orang tua dan pasien hipertensi. ${ }^{22}$ Maka dari itu asupan natrium berlebih berpengaruh pada homeostasis endotel dalam pembuluh darah dan apabila terjadi dalam waktu lama menyebabkan pembuluh darah menjadi tidak elastis. Kemudian kerusakan tersebut dapat dimodulasi oleh faktor genetik yang berkaitan dengan konsumsi natrium berlebih sehingga menjadi khas terjadinya hipertensi begitu seseorang memasuki usia lansia.

\section{SIMPULAN DAN SARAN}

Hasil penelitian menunjukkan tidak terdapat perbedaan rata-rata lingkar perut dan konsumsi karbohidrat dengan stage hipertensi, meskipun terdapat kecenderungan bahwa lingkar perut dan konsumsi karbohidrat lebih besar pada kelompok hipertensi stage 2 dibanding stage 1. Namun terdapat perbedaan rata-rata antara konsumsi natrium pada lansia penderita hipertensi primer stage 1 dengan 2. Diperkirakan ada faktor lain yang dapat dimodifikasi maupun tidak dapat dimodifikasi pada kejadian hipertensi primer lansia di Puskesmas Arjuno Kota Malang. Berdasarkan hasil penelitian diperlukan adanya pemberian edukasi kepada lansia di wilayah kerja Puskesmas Arjuno Kota Malang tentang pola makan gizi seimbang, rendah karbohidrat, dan rendah natrium untuk menjaga tekanan darahnya lebih stabil. Penelitian lebih lanjut diharapkan untuk memperlebar rentang umur ke arah lebih muda dan memperbanyak jumlah sampel untuk mendapatkan gambaran faktor pola makan dan gaya hidup yang mempengaruhi kejadian hipertensi lebih akurat.

\section{DAFTAR PUSTAKA}

1. Kementerian Kesehatan RI. Hipertensi Si Pembunuh Senyap. Pusat Data dan Informasi Kementerian Kesehatan RI [Internet]. 2019 [cited 2021 Mar 9];1-5. Available from: https://pusdatin.kemkes.go.id/resources/download/pusdatin/infodatin/infodatinhipertensi-si-pembunuh-senyap.pdf 
2. WHO. Hypertension [Internet]. who.int. 2019 [cited 2021 Mar 11]. Available from: https://www.who.int/news-room/fact-sheets/detail/hypertension

3. Kementerian Kesehatan RI. Hasil Utama Riset Kesehatan Dasar (RISKESDAS) 2018. Badan Penelitian dan Pengembangan Kesehatan [Internet]. 2018 [cited 2021 Mar 11];44(8):1-200. Available from:

https://kesmas.kemkes.go.id/assets/upload/dir_519d41d8cd98f00/files/Hasil-riskesdas2018_1274.pdf

4. Dinas Kesehatan Kota Malang. Data Jumlah Penduduk Kota Malang berdasarkan Penyakit. Malang; 2016.

5. Sari MK, Lipoeto NI, Herman RB. Hubungan Lingkar Abdomen (Lingkar Perut) dengan Tekanan Darah. Jurnal Kesehatan Andalas. 2016;5(2):456-461.

6. Kementerian Kesehatan RI. Epidemi Obesitas [Internet]. Web P2PTM. 2018 [cited 2021 Mar 12]. Available from: http://www.p2ptm.kemkes.go.id/dokumen-ptm/factsheetobesitas-kit-informasi-obesitas

7. Manawan AA, Rattu AJM, Punuh MI. Hubungan antara konsumsi makanan dengan kejadian hipertensi di Desa Tandengan satu Kecamatan Eris Kabupaten Minahasa. Jurnal IImiah Farmasi Pharmacon 2016;5(1):340-347.

8. Cahyahati JS, Kartini A, Rahfiludin MZ. Hubungan Asupan Makanan (Lemak, Natrium, Magnesium) Dan Gaya Hidup Dengan Tekanan Darah Pada Lansia Daerah Pesisir (Studi Di Wilayah Kerja Puskesmas Tegal Barat Kota Tegal). Jurnal Kesehatan Masyarakat 2018;6(5):395-403.

9. Kementerian Kesehatan RI. Klasifikasi Hipertensi [Internet]. Web P2PTM. 2018 [cited 2021 June 8]. Available from: http://p2ptm.kemkes.go.id/infographic-p2ptm/hipertensipenyakit-jantung-dan-pembuluh-darah/page/28/klasifikasi-hipertensi

10. Pusdatin Kemenkes RI. Hipertensi. Infodatin Pusat data dan Informasi Kementerian Kesehatan RI [Internet]. 2019 [cited 2021 June 19]. Available from: https://pusdatin.kemkes.go.id/resources/download/pusdatin/infodatin/infodatinhipertensi.pdf

11. Anggriani LM. Deskripsi Kejadian Hipertensi Warga RT 05 RW 02 Tanah Kali Kedinding Surabaya. Jurnal Promkes: The Indonesian Journal of Health Promotion and Health Education. 2016;4(2):151-164.

12. Yulanda G, Lisiswanti R. Penatalaksanaan Hipertensi Primer. Majority. 2017;6(1):2533.

13. Hastono S. Analisis Data pada Bidang Kesehatan (Cetakan 1). Jakarta: Rajawali Press; 2016.

14. Fauza A, Rosidi A. Sensitivitas dan Spesifisitas Rasio Lingkar Pinggang Panggul (RLPP) dan Lingkar Perut (LP) sebagai Indikator Risiko Hipertensi pada Orang Dewasa. 
NERS Jurnal Keperawatan. 2017;13(1):10-14.

15. Rumahorbo LJ, Fanggidae RS, Pakpahan M, Purimahua DI. Kajian Literatur: FaktorFaktor Yang Mempengaruhi Kejadian Hipertensi Pada Lansia [Literature Review: Factors That Affect the Incidence of Hypertension in Elderly]. Nursing Current Jurnal Keperawatan. 2020;8(1):1-18.

16. Mulyasari EW, Srimiati M. Asupan Zat Gizi Makro, Aktivitas Fisik dan Tingkat Stress dengan Kejadian Hipertensi pada Dewasa (18-60 Tahun). Jurnal IImiah Kesehatan. 2020;2(2):83-92.

17. Listiana L, Krisnasary A, Rizal A. Hubungan Pola Konsumsi Zat Gizi Makro Dan Mikro Dengan Tekanan Darah Pada Penderita Hipertensi. Jurnal Media Kesehatan. 2017;10(2):102-204.

18. Fadillah AD, Suyatno, Nugraheni SA. Faktor-Faktor yang Berhubungan dengan Kesesuaian Praktik Gizi pada Lansia Berdasarkan 10 Pesan Gizi Seimbang (Studi di Kelurahan Sambiroto Kota Semarang). Jurnal Kesehatan Masyarakat. 2019;7(4):70819.

19. Kurnianingtyas BF, Suyatno, Kartasurya MI. Faktor Risiko Kejadian Hipertensi pada Siswa SMA di Kota Semarang Tahun 2016. Jurnal Kesehatan Masyarakat. 2017;5(2):71-77.

20. Yulistina F, Deliana SM, Rustiana ER. Korelasi Asupan Makanan, Stres, dan Aktivitas Fisik dengan Kejadian Hitensi pada Usia Menopause. Unnes Journal of Public Health. 2017;6(1) 35-42.

21. Fayasari A, Salindri O. Asupan Natrium, Kalium, Dan Rasio Na-K Terhadap Hipertensi Di Puskesmas Sawangan Depok Tahun 2016. Jurnal Impuls Universitas Binawan. 2016;2:117-26.

22. Grillo A, Salvi L, Coruzzi P, Salvi P, Parati G. Sodium intake and hypertension. Nutrients. 2019;11(9):1-16. 